Agricultural Journal 6 (6): 392-399, 2011

ISSN: $1816-9155$

(C) Medwell Journals, 2011

\title{
The Effects of Sowbug (Hemilepistus shirazi Schuttz) on Some Physico-Chemical Properties of Soil in a Desert Region
}

\author{
${ }^{1}$ Gholam Reza Rahbar, ${ }^{1}$ Mohmed Musa Hanafi, ${ }^{2}$ Sayyed Ahang Kowsar and ${ }^{1}$ Radziah Othman \\ ${ }^{1}$ Department of Land Management, University Putra Malaysia, 43400 UPM, Serdang, Malaysia \\ ${ }^{2}$ Research Center for Agriculture, P.O. Box 71555-617, Shiraz, Iran
}

\begin{abstract}
Desertification control through Flood Water Spreading (FWS) mainly for the Artificial Recharge of Groundwater (ARG) is comprehensive study that is being implemented since Jan. 1963 in the Gareh Bygone Plain (GBP) in Southern of Iran. Total 8 ARG system with a total area of 1365 ha were constructed during the 1983-1987 period on the debris cone and alluvial fan formed by the Bisheh Zard river an ephemeral stream that supplies floodwater to the GBP from none to 8 times a year. The appearance of sowbugs (Hemilepistus shirazi Schuttz) in the sedimentation basins of the Artificial Recharge of Groundwater (ARG) systems in the Gareh Bygone Plain (GBP) in Southern Iran is considered an ecological breakthrough in desertification control. This crustacean which drills $7-8 \mathrm{~mm}$ holes down to $1.8 \mathrm{~m}$ in the freshly laid sediment and sand, facilitates preferential flow of water towards the aquifers. Particle size distribution, saturation percentage, $\mathrm{pH}$, Electrical Conductivity (EC) and concentration of major cations and anions, Cation Exchangeable Capacity (CEC) and trace elements were determined using the standard procedures. The burrowed material was highly concentrated in macro- and micro-elements. $\mathrm{pH}$ was lowered by 1.4 units in the same material. Saturation percentage of water has been increased 2-folds comparison with control. In this reason, sowbug can be in a desert region in the research station. The amount of total nitrogen in burrowed materials has changed 13-folds in comparison with control. The burrowed material was highly concentrated in organic carbon in comparison with control (7-folds) and show a significant difference in $1 \%$ level. The concentration of iron, zinc, manganese and copper due to sowbug activities have increased (3.13, 3.8, 4.9 and 12.7 -folds, respectively) and show a significant difference in $1 \%$ level. Results show that the physico-chemical properties of burrowed materials are more fertile in comparison with control. Moreover by bringing up, the excavated material sowbugs affect the surface soil composition in a long time.
\end{abstract}

Key words: Sowbug, desertification control, soil, physico-chemical properties, satwration percentage, Iran

\section{INTRODUCTION}

Malthusian dilemma shall be realized in about 100 years if the current trends of land degradation, conversion of prime farmlands to non-agricultural uses and population growth continue unchanged. Desertification control through floodwater spreading, particularly for the ARG on a very large scale, however may delay this ultimate crisis. In the meantime, scientific breakthroughs in birth control and food production may hopefully reverse this predicament. Implementation of the ARG methods in the deserts underlain with potential aquifers not only replenishes the underground reservoirs but also rehabilitates the drastically disturbed lands through sedimentation of nutritious suspended load that abounds in floodwater onto them (Kowsar, 1998). This at least in the land of Iran is mainly due to the extreme erosivity of the Miocene marls, siltstones and sandstones that cover most of the flood producing basins. These particles that are the nemeses of hydraulic engineers, particularly dam builders are a boon to conservationists as they utilize them to rehabilitate the eroded land and to transform the coarse-textured, infertile soils into productive fields.

Soil building in sedimentation basins, the integral part of the ARG systems has converted 1365 ha of a moving sand menance into a fertile land in the GBP in Southern Iran (Kowsar, 1991, 1998). One of the main theoretical constraints of this successful project was the inevitable impermeability of the ARG systems due to deposition of the suspended load onto the sedimentation basins and recharge ponds and the downward migration of fine clay particles, specifically those of chlorite, palygorskite and smectite through the soil profile (Mohammadnia and

Corresponding Author: Gholam Reza Rahbar, Department of Land Management, University Putra Malaysia, 43400 UPM, Serdang, Malaysia 
Kowsar, 1998). As sub-soiling is harmful to the tree roots planted in the basins and its effects are usually short lived, terminating with the next flood we had to resort to biological means. We knew that decomposition of Eucalyptus camaldulensis Dehnh. roots, planted in the basins would form channels that facilitate preferential flow towards the watertable. However, surface sealing by a very hard crust with an ever-increasing thickness would hinder the smooth flow of water toward the rooting zone. Therefore, drilling of numerous biopores in the crusts was the method of choice.

It is well known that various macro fauna inhabit the soil and modify some of its properties (Pankhurst and Lynch, 1994). Tunneling, mounding and pedoturbation are some of the most observable activities that have attracted the attention of soil scientists. Ants, beetles, termites, cicadas and crayfish are a few of the fauna whose activities which somehow resemble those of the sowbug have been studied.

Baxter and Hole (1967) investigated the ant (Formica cinerea montana Emery) activities in Grant county, Wisconsin. Salem and Hole (1968) studied the ant (Formica exsectoides Forel) mounds in Lafayette county, Wiscosin. Wiken et al. (1976) reported on the ant (Formica fusca L.) activities in Northeast of Mt.

Talow in British Columbia and Levan and Stone (1983) researched soil modification by Formica fusca L. in centeral New York. These investigators found ant tunnels at depths ranging from $120-150 \mathrm{~cm}$. Soil mixing by scarab beetles (Peltotrupes youngi) was studied by Kalisz and Stone (1984) in the Ocala national forest in Florida. Although, they measured burrows as deep as $3.6 \mathrm{~m}$, these researchers speculated that $P$. youngi may burrow down to $5 \mathrm{~m}$.

Mermut et al. (1984) and Jones (1989) studied termite mounds in Kenya and Tanzania, respectively. The latter investigator discovered indicator plants for the geological formations where specific species of termites were active. Luken and Kalisz reported that three cicada species (Magicicada cassini, M. sependesim and $M$. septendecula) that live underground for a period of either 13 or 17 years, burrow to a depth of $36 \mathrm{~cm}$. As their density may reach as high as $1,700,000 \mathrm{ha}^{-1}$, they should have quite an impact on soil infiltrability. Stone (1993) found that a crayfish (Procambarus rogersi Hobbs.) excavates galleries $4-10 \mathrm{~cm}$ in diameter and longer than $1.5 \mathrm{~m}$, chiefly in the upper $30 \mathrm{~cm}$ of soil but with vertical shafts deeper than $1 \mathrm{~m}$.

Although, all of the burrows made by the above mentioned animals could function as flow path for water and solutes this point was not an objective of these investigations. The appearance of many circular biopores next to quailbush [Atriplex lentiformis (Torr.) Wats.] in the spring of 1992, 10 years into the project was a glad tiding for us. Close examination revealed mild infestation of these bushes by a sowbug species (Hemilepistus shirazi Schuttz). Preliminary sounding of the burrows indicated the presence of a vertical shaft, $30-40 \mathrm{~cm}$ deep in each one. The rapid infiltration of floodwater into the hard crust formed by the dried fine sediment and perforated by the sowbug encouraged us to investigate different aspects of this very useful gift of Nature. This is the first in a series of reports that presents a brief description of the animal, the architecture of its burrows, infiltrability enhancement of the perforated crust and some physico-chemical properties of the extracted materials deposited on one side of each burrow.

Description of the sowbug: This organism is a crustacean, $10-15 \mathrm{~mm}$ long and $5 \mathrm{~mm}$ wide. It is blackish gray and has 7 pairs of legs (Fig. 1). Unlike pillbug, it is not capable of rolling up into a ball. This organism has been classified as follows (Robert, 1980):

Gategory: Metazoa

Phylum: Arthropoda

Subphylum: Mandibulate

Class: Crustacea

Order: Isopoda

Suborder: Oniscoidae

Genus: Hemilepistus

Sowbugs live in damp places, forage on vegetation and digest the soil organic matter. Their burrows, $7 \mathrm{~mm}$ in diameter and up to $80 \mathrm{~cm}$ deep, serve to aerate and drain the soil profile. The same genus or one of its close relatives burrows down to $100 \mathrm{~cm}$ in Gonabad, NE Iran (Rahimi, 1993). The Northward extension of Hemilepistus

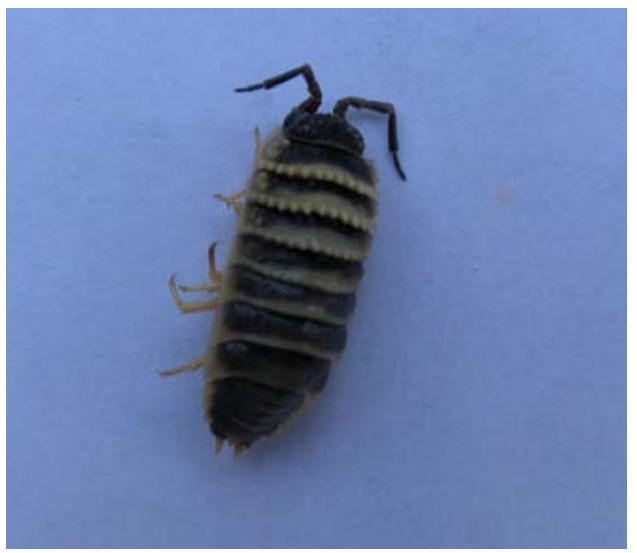

Fig. 1: A dorsal view of a female Hemilepistus shirazi Schuttz 


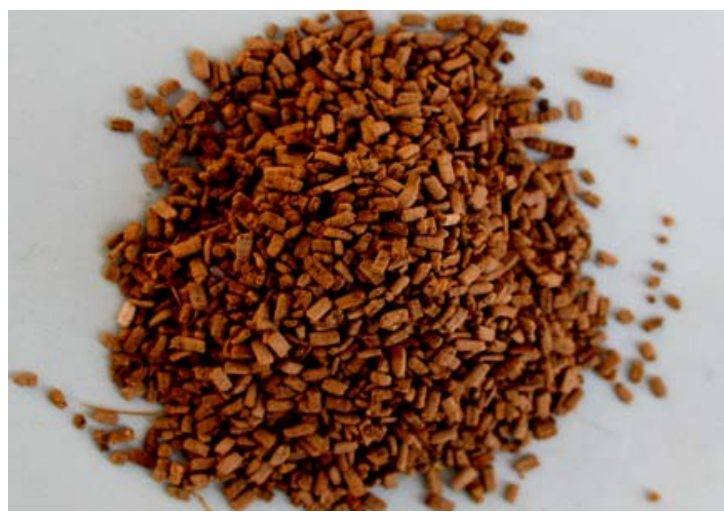

Fig. 2: Parallelepiped-shaped burrowed material

sp., reaches Central Asia where they may be found up to $100 \mathrm{~m}^{-2}$ burrowing down to $80 \mathrm{~cm}$ and excavating up to 1.5 ton $\mathrm{ha}^{-1}$ of soil in their active period of about 3 months. The excavated soil has more organic matter and a better structure thus is more resistant to erosion than the original soil form which it was extracted (Saleh Rastin, 1978). This viviparous organism lives for about 1 year. The white brood pouch under the abdomen of the female swells in March. The eggs form larvae in the pouch and 60-70 sowbugs very similar to their parents are released from the pouch in May. They are very active in the spring and fall. They come out of their burrows in the cool air of early morning and late afternoon.

It seems that digging deep into the soil is to reach a humid surrounding. There are semi-spherical spaces at the end of their burrows, $5-10 \mathrm{~cm}$ in diameter. They form semi-cylinderical, rods of soil, $2 \mathrm{~mm}$ long and $1 \mathrm{~mm}$ in diameter with their mandibule and place them to one side of the opening of their burrows (Fig. 2). These rods are seemingly more resistant to slaking than the freshly laid sediment from which they are formed. As some remains of the sowbug are found in scorpion burrows, it is believed that that Hemilepistus shirazi Schuttz is eaten by this arachnid.

\section{MATERIALS AND METHODS}

This study was performed at the Kowsar floodwater spreading and aquifer management research, training and extension station in the gareh bygone plain, $200 \mathrm{~km}$ to the SE of Shiraz, Iran on the debris cone of the Bisheh Zard river (Fig. 3). The major soil of the site is loamy sand (coarse-loamy over loamy skeletal, carbonatic (hyper) thermic and typic haplocalcids). A 8 ARG systems, covering a total area of 1365 ha were installed during the 1983-1988 period. More details may be found elsewhere

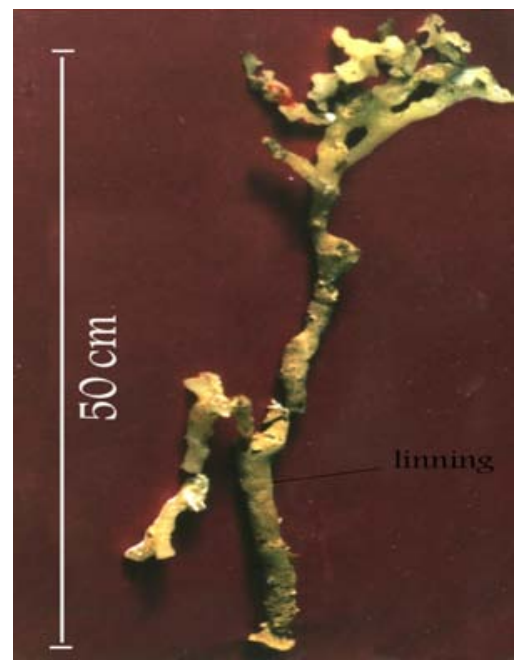

Fig. 3: Paraffin wax cast of a sowbug burrow. The opening is on the top

(Kowsar, 1991, 1998). Configuration of the burrows was studied by making their paraffin casts. Measured volumes of molten paraffin wax were poured into the burrows through a long stemmed glass funnel. The casts were removed from the soil profile by digging diligently around them making sure that the broken pieces were placed in proper order then photographing them (Fig. 4). It should be mentioned that the lateral penetration of the molten wax into the wall of the burrows made the cast diameter 4-5 times their true measurement of $7 \mathrm{~mm}$.

The walls of sowbug burrows are quite durable. Apparently, the sowbug wet and cement their burrows with the body fluids. An extremely thin coating of a grayish material lines the burrows in very fine sand that collapse otherwise.

There are 8 floodwater spreading system about 1368 ha in extent in the GBP. To characterize some of the physico-chemical properties of the sowbug burrowed materials, the BZ1 system was selected. The system on which this research was conducted was the first in a series of 8 systems constructed in Gareh Bygone plain since 1983. This system has 6 sedimentation basin (Fig. 5). I chose the second sedimentation basin of this system as the sowbugs were very active there.

About $2 \mathrm{~kg}$ of the rod-shaped soil (burrowed material) were collected from 70 sowbug infested plots (10-20 g adjacent to each) opening. These samples were thoroughly mixed. The same amount of surface soil (freshly laid sediment) was also taken from the adjacent plot without the burrows as the control. This sample was thoroughly mixed too. Particle size distribution (sand, silt and clay), saturation percentage, $\mathrm{EC}, \mathrm{pH}$, bicarbonate, 
Agric. J., 6 (6): 392-399, 2011

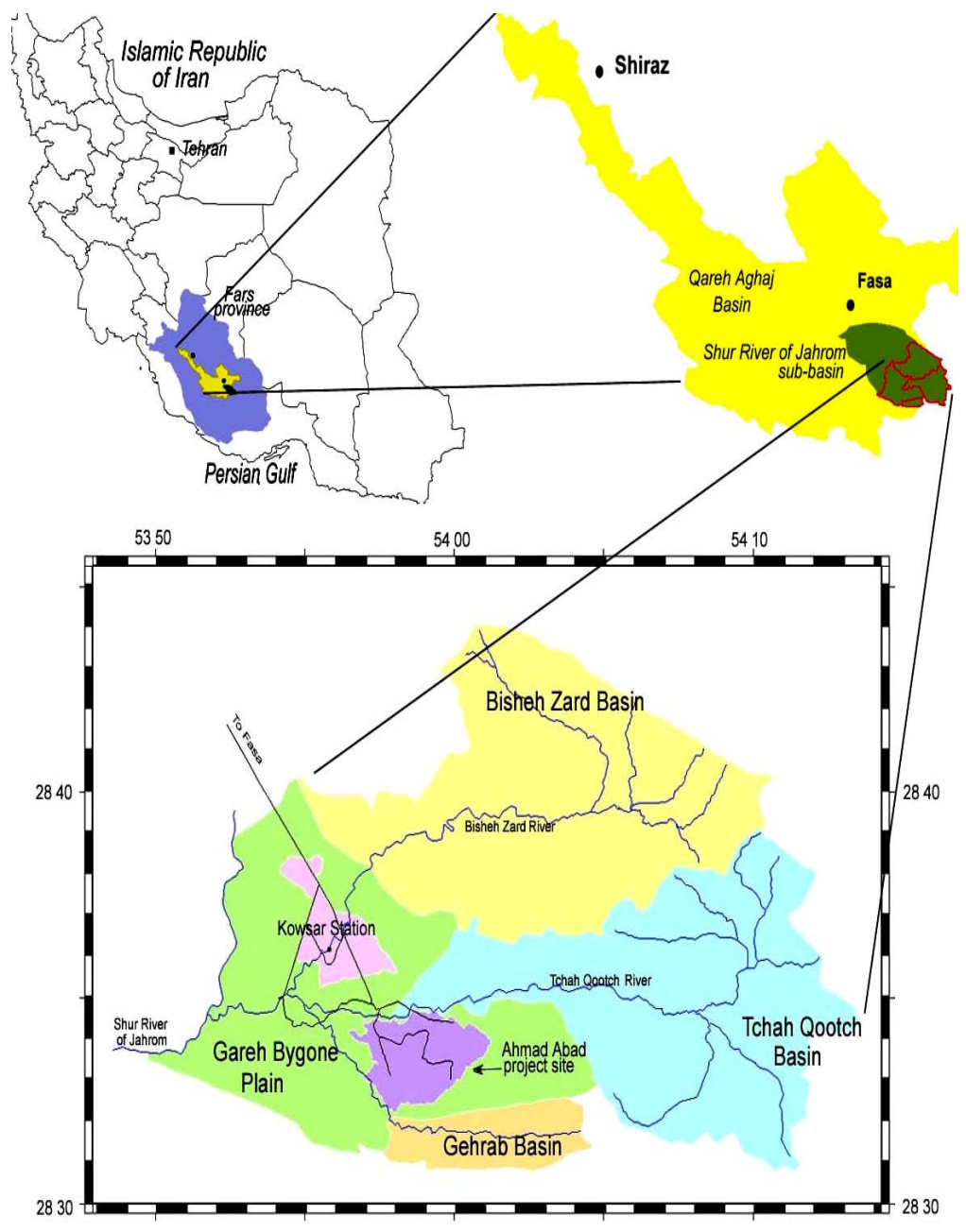

Fig. 4: The map of site study

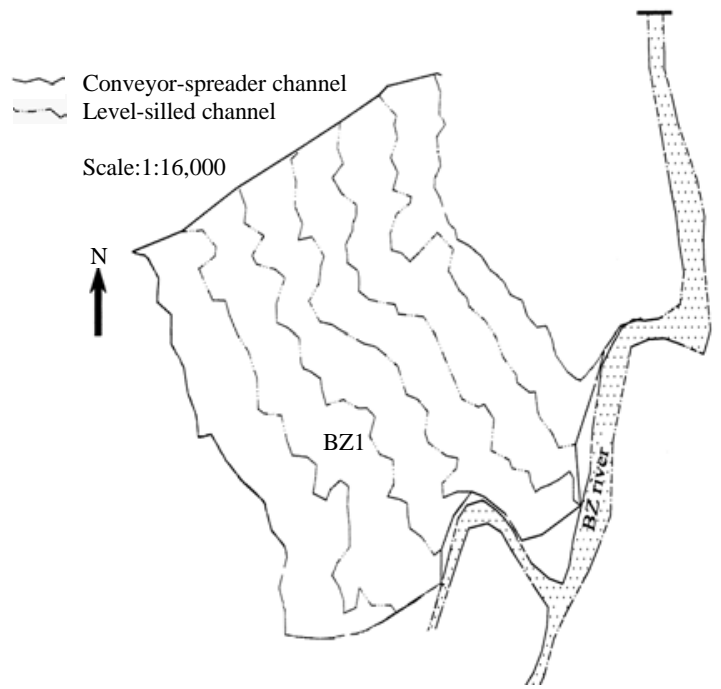

Fig. 5: The BZ1 floodwater spreading system carbonate, Cation Exchange Capacity (CEC), organic carbon, potassium, phosphorus, total nitrogen, iron, copper, magnesium, zinc and the dissolved cation and anion were determined using the standard procedures.

\section{RESULTS AND DISCUSSION}

Chi-square $\left(\chi^{2}\right)$ test was used to compare the physicochemical properties of the burrowed materials and the freshly laid sediment (control): Chi-square $\left(x^{2}\right)$ test obtained as following:

$$
\chi^{2}=\sum_{i=1}^{k} \frac{\left(\mathrm{O}_{\mathrm{i}}-\mathrm{E}_{\mathrm{i}}\right)^{2}}{\mathrm{E}_{\mathrm{i}}}
$$

Where:

$\mathrm{O}_{\mathrm{i}}=$ Sowbug

$\mathrm{E}_{\mathrm{i}}=$ Without sowbug (Check) 
Agric.J., 6 (6): 392-399, 2011

Table 1: Chi-square distribution and significant level table for sowbug Burrowed materials

\begin{tabular}{|c|c|c|c|}
\hline Variables & $\chi^{2}$ & Sig. & \\
\hline Sand (\%) & 37.79 & 0.000 & 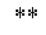 \\
\hline Silt (\%) & 399.55 & 0.000 & 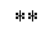 \\
\hline Clay $(\%)$ & 61.28 & 0.000 & $* * *$ \\
\hline Water satu. per. & 209.56 & 0.000 & *** \\
\hline $\mathrm{pH}$ & 1.81 & 0.874 & NS \\
\hline $\mathrm{EC}$ & 70.07 & 0.000 & $* * *$ \\
\hline O.C. (\%) & 404.30 & 0.000 & $* * *$ \\
\hline Ava. $\mathrm{K}$ & 112169.23 & 0.000 & $* * *$ \\
\hline Ava. $\mathrm{P}$ & 738.06 & 0.000 & *** \\
\hline T.N. (\%) & 37.34 & 0.000 & *** \\
\hline CCE (\%) & 1.26 & 0.939 & NS \\
\hline $\mathrm{Fe}$ & 92.91 & 0.000 & *** \\
\hline $\mathrm{Zn}$ & 29.92 & 0.000 & $* * *$ \\
\hline $\mathrm{Cu}$ & 925.80 & 0.000 & $* * *$ \\
\hline $\mathrm{Mn}$ & 5757.53 & 0.000 & $* * *$ \\
\hline $\mathrm{K}^{+}$ & 90.18 & 0.000 & $* *$ \\
\hline $\mathrm{Na}^{+}$ & 678.75 & 0.000 & *** \\
\hline $\mathrm{Mg}^{2+}$ & 1146.59 & 0.000 & $* * *$ \\
\hline $\mathrm{Ca}^{2+}$ & 632.83 & 0.000 & *** \\
\hline $\mathrm{Cl}^{-}$ & 1540.95 & 0.000 & *** \\
\hline $\mathrm{SO}_{4}^{2-}$ & 263.25 & 0.000 & 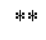 \\
\hline $\mathrm{HCO}_{3}^{-}$ & 786.31 & 0.000 & $* * *$ \\
\hline $\mathrm{CO}_{32}$ & 1.20 & 0.945 & NS \\
\hline CEC & 34.73 & 0.000 & **** \\
\hline
\end{tabular}

$\chi^{2}(0.05,5)=11.07 ; \chi^{2}(0.01,5)=15.09$

$$
\begin{gathered}
\chi^{2}=111.446 * * \\
\chi^{2}(5,10)=18.307 \\
\chi^{2}(1,10)=23.209
\end{gathered}
$$

According to obtained amount and degrees of freedom $(\mathrm{K}-1)$, the value of $\chi^{2}$ was calculated and compared with the Chi-square distribution table (Table 1). Because the amount of calculated is much more than obtained amount from Table $1(37.09>15.79)$. Therefore, we can confidently claime that most of element exception carbonate calcium and $\mathrm{pH}$ is greater than freshly laid concentration (control) and show a significant different in $1 \%$ level.

As there were only two treatments, the burrowed materials and the freshly laid sediment (control) the Paired t-test was used to detect the significance of the sowbug activities.

The SPSS 1.6 and Excell Softwares were used for the analysis of the data (Table 2 and 3). Establishment of a forest in a sandy desert is one of the most important effects of floodwater spreading as it has fixed the moving sand, eliminated the dust and created a better environment for the wildlife in the Gareh Bygone plain. Desertification control through floodwater spreading and planting trees and shrubs has changed this
Table 2: Selected characteristics of the rod-shaped soil excavated by the

\begin{tabular}{|c|c|c|c|c|}
\hline $\begin{array}{l}\text { Selected } \\
\text { characteristics }\end{array}$ & $\begin{array}{l}\text { (Freshly-laid } \\
\text { sediment) }\end{array}$ & $\begin{array}{l}\text { Burrowed } \\
\text { materials }\end{array}$ & $\begin{array}{c}\text { Significance } \\
\text { level }\end{array}$ & $\mathrm{CV}$ \\
\hline Sand (\%) & $79.98 \pm 5.7^{\mathrm{a}}$ & $60.00 \pm 5.00^{\mathrm{a}}$ & 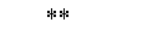 & 7.69 \\
\hline Silt $(\%)$ & $12.00 \pm 4.2^{b}$ & $29.00 \pm 11.6^{\mathrm{a}}$ & $*$ & 14.20 \\
\hline Clay (\%) & $8.17 \pm 3.40^{\mathrm{a}}$ & $11.24 \pm 6.9^{a}$ & NS & 16.00 \\
\hline Saturation percentage & $33.52 \pm 2.70^{b}$ & $66.10 \pm 63^{\mathrm{a}}$ & $* *$ & 9.92 \\
\hline $\mathrm{pH}$ & $8.3 \pm 0.27^{\mathrm{a}}$ & $6.74 \pm 0.4^{b}$ & 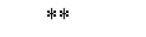 & 4.53 \\
\hline $\mathrm{EC} \mathrm{ds} / \mathrm{m}$ & $2.60 \pm 0.27^{\mathrm{a}}$ & $0.43 \pm 0.27^{\mathrm{a}}$ & *** & 5.30 \\
\hline O.M. & $0.95 \pm 0.92^{b}$ & $6.63 \pm 1.80^{\mathrm{a}}$ & $* *$ & 13.70 \\
\hline Calcium carbonate & $40.89 \pm 2.82^{\mathrm{a}}$ & $42.10 \pm 2.40^{b}$ & $*$ & 6.53 \\
\hline Available K & $101.20 \pm 0.88^{b}$ & $1397 \pm 8.80^{\mathrm{a}}$ & $*$ & 18.30 \\
\hline Available P & $12.75 \pm 3.77^{b}$ & $52.50 \pm 17.8^{b}$ & $*$ & 13.00 \\
\hline Total nitrogen & $0.047 \pm 6.002^{b}$ & $0.61 \pm 0.04^{\mathrm{a}}$ & *** & 10.30 \\
\hline $\mathrm{Fe}$ & $2.31 \pm 0.88^{b}$ & $7.25 \pm 1.92^{\mathrm{a}}$ & *** & 21.00 \\
\hline $\mathrm{Zn}$ & $0.49 \pm 0.19^{b}$ & $1.84 \pm 0.53^{\mathrm{a}}$ & $* *$ & 14.00 \\
\hline $\mathrm{Cu}$ & $0.49 \pm 0.19^{b}$ & $1.87 \pm 0.53^{\mathrm{a}}$ & $* *$ & 14.00 \\
\hline $\mathrm{Mn}$ & $13.53 \pm 6.11^{\mathrm{b}}$ & $66.50 \pm 18^{\mathrm{a}}$ & *** & 12.40 \\
\hline Dissolved Po. & $1.93 \pm 1.70^{\mathrm{a}}$ & $6.53 \pm 5.9^{a}$ & NS & 10.30 \\
\hline Dissolved sodium & $0.63 \pm 0.50^{b}$ & $10.02 \pm 4.6^{\mathrm{a}}$ & *** & 16.50 \\
\hline Dissolved Mag. & $2.22 \pm 0.67^{\circ}$ & $21.80 \pm 8.8^{\mathrm{a}}$ & *** & 15.00 \\
\hline Dissolved calcium & $2.17 \pm 0.20^{\mathrm{a}}$ & $16.78 \pm 12.44^{b}$ & $*$ & 14.30 \\
\hline Dissolved chlorine & $2.7 \pm 1.17^{\mathrm{b}}$ & $25 \pm 8.37^{\mathrm{a}}$ & $* *$ & 14.20 \\
\hline Dissolved sulphate & $1.15 \pm 0.52^{b}$ & $7.35 \pm 3.68^{a}$ & $*$ & 16.20 \\
\hline Dissolved Bica. & $2.65 \pm 1.18^{b}$ & $22.05 \pm 12.6^{\mathrm{a}}$ & $*$ & 17.50 \\
\hline Dissolved Car. & $0.65 \pm 0.9^{a}$ & $0.00^{\mathrm{a}}$ & NS & 19.50 \\
\hline $\mathrm{CEC}$ & $8.15 \pm 0.315^{b}$ & $13.98 \pm 0.108^{a}$ & *** & 5.37 \\
\hline
\end{tabular}
sowbugs and the surface soil of the sedimentation basins and the Paired t-test

drastically disturbed land. Invasion of the terrestrial sowbug was mainly due to the provision of forage and water for this environmentally benign creature. This crustacean has been seen in Sarvestan, Lar and Abadeh in the Province of Fars. Sowbug is herbivorous in the processes of building its nest, it mixes the subsoil and the topsoil.

The number of sowbug changes in different seasons. Their population is estimated at about 10,00,000 in 1 ha. Their population is higher in October and March in the Gareh Bygone plain as compared with other months. The number of burrow is about $20000 \mathrm{ha}^{-1}$ and there are about 50-60 sowbugs in each burrow. Sowbug makes humus from the litter and residues of plants by its mouth parts. Because of sowbugs use litter and plant residue, they have an important role in the biological cycle. Soil forming trend accelerates by sowbug in artificial recharge system that is a big distinction. Studies show that terrestrial living things are very important in soil physico-chemical changes. Table 1-3 show that the burrowed materials texture has changed from loamy sand to a sandy loam and this texture is more suitable for the plant growth.

Statistical analyses show a significant difference at the $1 \%$ level for numerous soil characteristics as compared with those of the control. Most trees and shrubs need a loamy texture for good growth. It seems that the preference of the sowbugs for the finer material and a more productive soil having a lower percentage of sand and a percentage of silt, thus a higher water holding 
Agric. J., 6 (6): 392-399, 2011

Table 3: Statistical parameters and the Paired t-test results for the paired samples statistics between the means of the treated and control

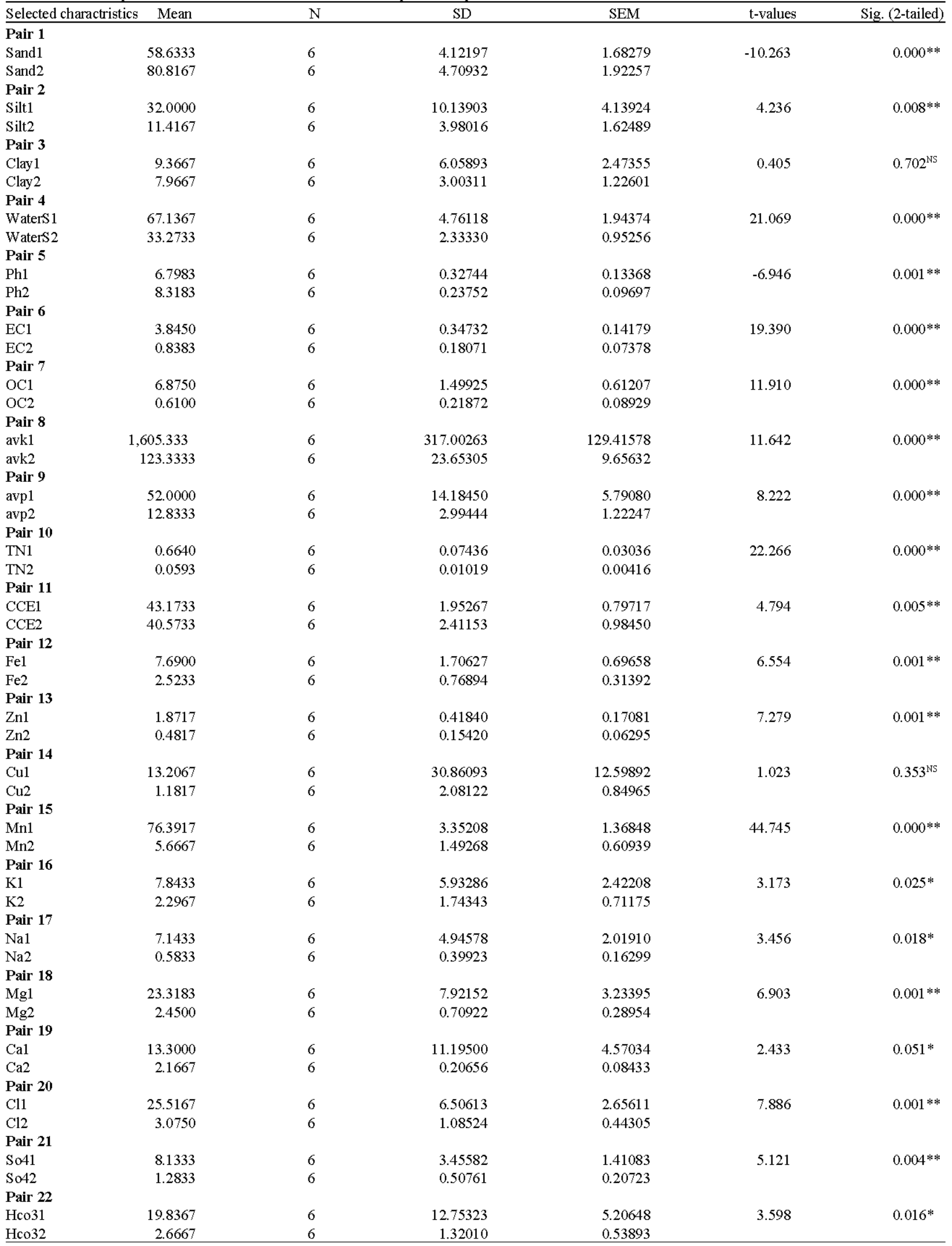


Agric. J., 6 (6): 392-399, 2011

\begin{tabular}{|c|c|c|c|c|c|c|}
\hline Selected charactristics & Mean & $\mathrm{N}$ & $\mathrm{SD}$ & SEM & $\mathrm{t}$-values & Sig. (2-tailed) \\
\hline \multicolumn{7}{|l|}{ Pair 23} \\
\hline Co31 & 0.0000 & 6 & 0.00000 & 0.00000 & - & - \\
\hline $\mathrm{Co} 32$ & 0.2000 & 6 & 0.00000 & 0.00000 & & \\
\hline \multicolumn{7}{|l|}{ Pair 24} \\
\hline CEC1 & 14.4450 & 6 & 0.54051 & 0.22066 & 22.110 & $0.000^{* * *}$ \\
\hline $\mathrm{CEC} 2$ & 7.8017 & 6 & 0.54920 & 0.22421 & & \\
\hline
\end{tabular}

capacity has lured them to the sedimentation basins. It is no wonder that plants grow better within the sedimentation basins as compared to the area outside of them. The burrowed material texture has changed from loamy sand to sandy loam. Saturation percentage of water has increased 3-fold as compared with the control (significant difference at the 1\% level: Table 1-3). It may be the reason why the sowbug has invaded the research station. The phosphorus content of the burrowed material increased by about 4.5-fold as compared with that of the control and shows a significant difference at the $5 \%$ level (Table 2 and 3). Soil electrical conductivity increased significantly as compared with that of the control. This increase was due to the sowbug consumption of the leaves of Atriplex lentiformis, which resulted in salt accumulation in its excreta. As the sowbug feeds on the litter residues, soil organic carbon has increased about 6 -fold and show a significant difference at the $1 \%$ level compared with that of the control. It may also probably be due to a decrease in the soil $\mathrm{pH}$.

The burrowed materials were highly concentrated in organic carbon in comparison with control (7-fold) and show a significant difference in $1 \%$ level (Table 2 and 3 ). Soil organic matter plays a crucial role in the function of terrestrial ecosystem and is closely liked with a wide range of ecosystem services. The total nitrogen content has increased about 13-fold due to the sowbug activity as compared with that of the control and shows a significant difference at the $1 \%$ level. This can be very important because nitrogen is the main protein component and it is needed for the normal growth of plants.

Arid regions are poor in nitrogen. Adding nitrogen fertilizes to this soil is one way to compensate the loss of soil nitrogen. The excessive use of nitrogen fertilizers in both developed and developing countries causes unpleasant environmental problems groundwater pollution. However, $\mathrm{N}$ accumulation by the sowbug is the recycling of a precious resource. The lower $\mathrm{pH}$ (1.6 unit) and higher saturation percentage of the treated soil is due to its higher organic matter conten and show a significant difference in $1 \%$ level.

A decrease in soil $\mathrm{pH}$ and an increase in organic matter, phosphorus and nitrogen cause lead to an increase in micronutrients. Soils of arid and semi-arid regions are poor in these constituents. As such decrease hardly possible in farm fields and it incurs at high costs therefore this function of the sowbug is also remarkable. This decrease in the $\mathrm{pH}$ is worthwhile because the soils of arid regions are usually poor in micronutrients.

Micro-nutrients such as iron, zinc, manganese and copper have increased due to the activity of sowbugs and show a significant difference at the $1 \%$ level as compared with the control. Concentrations of iron, zinc, manganese and copper have increased 3.13, 3.8, 4.9 and 12.7-fold, respectively.

Micro-nutrients are very important in the biological processes; they are involved in enzymes reaction and they are essential for photosynthesis process. Concentrations of soluble cations $\left(\mathrm{K}^{+}, \mathrm{Na}^{+}, \mathrm{Mg}^{2+}\right.$ and $\left.\mathrm{Ca}^{2+}\right)$ and soluble anions $\left(\mathrm{Cl}^{-}, \mathrm{SO}_{4}{ }^{2-}, \mathrm{CO}_{3}{ }^{2-}\right.$ and $\left.\mathrm{HCO}_{3}^{-}\right)$have increased in burrowed materials as compared with those of the control and show the significant difference at the $1 \%$ level. This is mainly due to the calcareous shell of this crustacean. Calcium carbonate content in burrowed material shows a significant difference at the $1 \%$ level as compared with that of the control. Calcium carbonate is important in soil as it helps aggregation of soil particles. Aggregation enhances soil surface resistance to erosion and it also increases infiltration rate. Rersearchers believe that the very high contents of $\mathrm{Ca}$ and $\mathrm{Mg}, 5$ and 10 -fold, respectively is due to the addition of sowbug carcasses to the burrowed soils. Physico-chemical properties of burrowed materials are more fertile in comparison with control.

Cation Exchangeable Capacity (CEC) of the burrowed materials has increased and shows a significant difference at the $1 \%$ level as compared with that of the control. An overall improvement in the soil physico-chemical properties of the soil enhances its productivity. This matter has been reported for other terrestrial organism, especially earthworms and termites. Results show that the physico-chemical properties of burrowed materials are more fertile in comparison with control.

\section{CONCLUSION}

Extending the economic life of the artificial recharge of groundwater systems is a challenge to the planners and implementers of these facilities. The surface geology of most of the flood-producing watersheds makes their 
runoff highly turbid; therefore very large sedimentation basins have to be incorporated into the design. However, the presence of very fine particles, particularly clay minerals such as chlorite, palygorskite and smectite cause rapid clogging of these basins and infiltration ponds. Although, root channels enhance percolation, infiltrability of the basins and ponds is highly decreased by crust formation. Activity of the sowbug is beneficial for improvement of soil physical conditions and thus, plant growth. Burrowing by the sowbug improves air and water penetration into the soil.

The burrowed materials and castings resist erosion more than the freshly laid sediment from which they are formed. The sowbugs activity also improves the chemical properties of soil and makes it more fertile. They increase soil organic carbon content that plays a central role in the productivity of the soil and environmental quality. The higher soil organic carbon in the burrowed material as compared with those of the original soil a nd the freshly laid sediment, represents a potential for carbon sequestration when viewed as a long-term management system. They also increase micro-nutrient contents in the soil that is so important for arid and semi-arid region. Invasion of the sowbug to the ARG systems in the Gareh Bygone Plain in 1993 changed the picture. These crustaceans which sometimes make up to 10 burrow $\mathrm{m}^{-2}$ with depths down to $185 \mathrm{~cm}$ have increased infiltration rates up to 4-fold. As they feed on quailbush, it seems prudent to introduce this browse plant into the systems even for the sole purpose of attracting the sowbugs. Needless to say this plant can support four sheep, the year round if planted at a density of 625 bushes ha $^{-1}$, quite a feat for a sandy desert. Domestication of this organism, a souvenir of the ARG systems seems technically practicable, environmentally sound, economically feasible and socially acceptable.

\section{REFERENCES}

Baxter, F.P. and F.D. Hole, 1967. Ant (Formica cinerea) pedoturbation in a prairie soil. Soil Sci. Soc. Am. Proc., 31: 425-428.

Jones, J.A., 1989. Environmental influence on soil chemistry in central semiarid Tanzania. Soil Sci. Soc. Am. J., 53: 1748-1758.
Kalisz, P.J. and E.L. Stone, 1984. Soil mixing by scarab beetles and pocket gophers in North-Central Florida. Soil Sci. Soc. Am. J., 48: 169-172.

Kowsar, A., 1991. Floodwater spreading for desertification control: An integrated approach. Des. Con. Bull. (UNEP), 19: 3-18.

Kowsar, S.A., 1998. Aquifer management: A key to food security in the deserts of the Islamic Republic of Iran. Des. Con. Bull. (UNEP), 33: 24-28.

Levan, M.A. and E.L. Stone, 1983. Soil modification by colonies of black meadow ants in a New York old field. Soil Sci. Soc. Am. J., 47: 1192-1195.

Mermut, A.R., M.A. Arshad and R.J.S. Arnaud, 1984. Micropedological study of termite mounds of three species of macrotermes in Kenya. Soil Sci. Soc. Am. J., 48: 613-620.

Mohammadnia, M. and S.A. Kowsar, 1998. Clay translocation beneath the artificial recharge of groundwater system. Proceedings of the International Symposium on Comprehensive Watershed Management, Sep. 7-10, Beijing, China, pp: 558-564.

Pankhurst, C.E. and J.M. Lynch, 1994. The Role of Soil Biota in Sustainable Agriculture. In: Soil Biota: Management in Sustainable Farming Systems, Pankhurst, C.E., B.N. Doube and P.R. Grace (Eds.). CSIRO, Australia, pp: 3-8.

Rahimi, H., 1993. Morphological and biological characteristics of sowbug. Zeitun: Sci. Specific Monthly Agric., 115: 36-38.

Robert, D.B., 1980. Invertebrate Zoology. Saunders International, Australia.

Saleh Rastin, N., 1978. Soil biology: Soil inhibiting organisms and their role in distribution of elements. Publication No. 1666, Tehran University, Iran, pp: 482.

Salem, M.Z. and F.D. Hole, 1968. Ant (Formica exsectoides) pedoturbation in a forest soil. Soil Sci. Soc. Am. Proc., 32: 563-567.

Stone, E.L., 1993. Soil burrowing and mixing by a crayfish. Soil Sci. Soc. Am. J., 57: 1096-1099.

Wiken, E.B., K. Broersma, L.M. Lavkulich and L. Farstad, 1976. Biosynthetic alteration in a British Columbia soil by ants (Formica fusca L.). Soil Sci. Soc. Am. J., 40: 4-4. 